\title{
Effect of Supplemental Conjugated Linoleic Acids on Heat-Stressed Brown Swiss and Holstein Cows*
}

\author{
C. E. Moore, J. K. Kay, R. J. Collier, M. J. VanBaale, and L. H. Baumgard \\ Department of Animal Sciences, The University of Arizona, Tucson 85721
}

\begin{abstract}
Heat-stressed dairy cattle are bioenergetically similar to early-lactation cows in that dietary energy may be inadequate to support maximum milk and milk component synthesis. Study objectives were to evaluate whether conjugated linoleic acids- (CLA-) induced milk fat depression (MFD) during heat stress would allow for increased milk and milk component synthesis. In addition, CLA effects on production variables and its ability to induce MFD were compared between Holstein and Brown Swiss cows. Multiparous cows ( $\mathrm{n}=8$, Holstein; $\mathrm{n}=5$, Brown Swiss) averaging $97 \pm 17 \mathrm{~d}$ in milk were used in a crossover design during the summer (mean temperature-humidity index $=75.7$ ). Treatment periods were $21 \mathrm{~d}$ with a 7 -d adaptation period before and between periods. During adaptation periods, all cows received a supplement of palm fatty acid distillate (242 g/d). Dietary treatment consisted of $250 \mathrm{~g} / \mathrm{d}$ of CLA supplement (78.9 g/d of CLA) or $242 \mathrm{~g} / \mathrm{d}$ of palm fatty acid distillate to provide equal amounts of fatty acids. The CLA supplement contained a variety of CLA isomers $(3.0 \%$ trans -8 , cis- $10 ; 3.4 \%$ cis -9 , trans $-11 ; 4.5 \%$ trans-10, cis-12; and $4.8 \%$ cis-11, trans-13 CLA). Treatments were applied $2 \times / \mathrm{d}$ with half of the supplement top-dressed at $0600 \mathrm{~h}$ and the remainder top-dressed at $1800 \mathrm{~h}$. There was no overall treatment effect on dry matter intake $(23.9 \mathrm{~kg} / \mathrm{d})$, milk yield $(40.0 \mathrm{~kg} / \mathrm{d})$, somatic cell count $(305,000)$, protein $(2.86 \%)$, or lactose content $(4.51 \%)$ or yields of these milk components. Supplementation with CLA decreased overall milk fat content and yield by 26 and 30\%, irrespective of breed. The reduction of milk fat content and yield was greatest on $\mathrm{d} 21$ (28 and 37\%, respectively). Energy availability predicted by energy balance was improved with CLA supplementation compared with controls (3.7 vs. $7.1 \mathrm{Mcal} /$ d, respectively). Respiration rate (78 breaths/min) and skin temperature $\left(35.4^{\circ} \mathrm{C}\right)$ during maximum heat load
\end{abstract}

Received August 31, 2004.

Accepted January 11, 2005.

Corresponding author: Lance H. Baumgard; e-mail: baumgard@ ag.arizona.edu.

*This work was partially supported by the University of Arizona Experiment Station \#ARZT-136339-H-24-130. were not affected by treatment. The group receiving CLA had higher total milk fat CLA concentration (9.3 vs. $4.9 \mathrm{mg} / \mathrm{g}$ ). Supplementation with CLA induced MFD and altered milk fat composition similarly between breeds and improved calculated energy balance during heat stress, but had no effect on production measures under these conditions.

(Key words: conjugated linoleic acids, milk fat, heat stress, energy balance)

Abbreviation key: bpm = breaths per minute, CLA = conjugated linoleic acids, EBAL = energy balance, MFD = milk fat depression, $\mathbf{R I}=$ rumen-inert, $\mathbf{T H I}=$ temperature-humidity index.

\section{INTRODUCTION}

Conjugated linoleic acids (CLA) are a group of linoleic acid isomers containing conjugated double bonds, and are primarily found in ruminant food products (Bauman et al., 2001). This family of fatty acids alleviates or improves symptoms or measures of many common human diseases in animal models, ranging from atherosclerosis to cancer (see reviews by Whigham et al., 2000; Belury, 2002). In addition, dietary CLA reduces carcass fat content in many rodent species and pigs (ThielCooper et al., 2001; Terpstra et al., 2002) and CLA supplementation dramatically decreases milk fat synthesis in rodents, pigs, cattle, and women (see review by Bauman et al., 2001). Many studies confirmed that abomasally infused CLA caused milk fat depression (MFD; Loor and Herbein, 1998; Chouinard et al., 1999; Mackle et al., 2003) in lactating dairy cows and identified trans-10, cis-12 as a responsible CLA isomer (Baumgard et al., 2000; 2002a). Research utilizing rumen-inert (RI) CLA supplements $\left(\mathrm{Ca}^{++}\right.$salts) indicates that RI-CLA also decreases milk fat when fed to cows either consuming a TMR or rotationally grazed (Giesy et al., 2002; Perfield et al., 2002; Kay et al., 2004b; Moore et al., 2004). Therefore, RI-CLA may be a tool used to govern milk fat synthesis at times when energy required for production of milk fat could be used for the synthesis of additional milk or alternative milk components or to support a different physiological state (i.e., reproduction). 
Heat stress negatively affects milk synthesis and impairs reproductive performance (West, 2003). As a consequence, heat stress is a significant financial burden in many dairy-producing areas of the United States and the world. The bioenergetic mechanism by which heat stress affects production and reproduction is partly explained by reduced feed intake, but also includes altered endocrine status, reduction in rumination and nutrient absorption, and increased maintenance requirements (Collier and Beede, 1985; Collier et al., 2005) resulting in a net decrease in nutrient/energy availability for production. This decrease in energy results in a reduction in energy balance (EBAL), and explains why cows lose significant amounts of body weight when subjected to heat stress. Dietary strategies to alleviate this energy deficit traditionally include increasing the energy density of the diet with concentrates or fat supplements (Knapp and Grummer, 1991; Chan et al., 1997; Drackley et al., 2003). An alternative method of improving EBAL during heat stress is to reduce milk fat synthesis, as this may attenuate or eliminate the deleterious effects of environmental heat on production and reproduction. Reducing the energy requirement for milk fat synthesis may allow for increased synthesis of milk or other milk components and could provide a signal to allow for improved reproduction. We hypothesized that reducing milk fat synthesis during heat stress, a time when nutrient availability may limit production, may allow for energy partitioning to support increased synthesis of milk and milk protein (Bauman et al., 2001; Baumgard et al., 2002b; Collier et al., 2005) as observed from cows on pasture in established lactation (Medeiros et al., 2000; Mackle et al., 2003). In addition to enhancing milk yield, inhibiting milk fat synthesis and thus improving EBAL may improve animal well being and reproductive success. Furthermore, this study was designed to characterize the effects of heat stress and CLA-induced MFD on Brown Swiss compared with Holstein cattle.

\section{MATERIALS AND METHODS}

\section{Design, Animals, and Treatments}

The University of Arizona Institutional Animal Care and Use Committee approved all procedures involving animals. Thirteen multiparous cows $(\mathrm{n}=8$, Holstein and $\mathrm{n}=5$, Brown Swiss) averaging $97 \pm 17$ DIM and $730 \pm 14 \mathrm{~kg}$ BW were used in a crossover design between July 24 and September 24, 2003, a time of the year when the combination of heat and humidity are typically at their maximum in Tucson, AZ. Treatment periods ( $\mathrm{n}=$ 2 ) were $21 \mathrm{~d}$ with a 7 -d adaptation before the first treatment period as well as between the 2 treatment periods.
Table 1. Fatty acid composition of lipid supplements in control and conjugated linoleic acids (CLA) supplemented diets. ${ }^{1}$

\begin{tabular}{|c|c|c|}
\hline \multirow[b]{2}{*}{ Fatty acid } & \multicolumn{2}{|c|}{ Diet supplement } \\
\hline & Control & CLA \\
\hline & - $\%$ & $\mathrm{~s} \longrightarrow$ \\
\hline $12: 0$ & 0.24 & 0.18 \\
\hline $14: 0$ & 1.13 & 0.55 \\
\hline $15: 0$ & 0.06 & 0.02 \\
\hline $16: 0$ & 47.61 & 23.63 \\
\hline $16: 1$ & 0.16 & 0.20 \\
\hline 18:0 & 4.48 & 3.50 \\
\hline $18: 1$ cis -9 & 35.53 & 36.71 \\
\hline $18: 2$ cis -9, cis -12 & 7.66 & 3.27 \\
\hline 18:2 cis- 9 , trans-11 CLA & $<0.01$ & 3.44 \\
\hline 18:2 trans -8, cis -10 CLA & $<0.01$ & 2.99 \\
\hline 18:2 cis- 11 , trans -13 CLA & $<0.01$ & 4.82 \\
\hline 18:2 trans -10, cis -12 CLA & $<0.01$ & 4.52 \\
\hline Other CLA & $<0.01$ & 12.59 \\
\hline $18: 3$ cis -9, cis -12, cis -15 & 0.26 & 0.70 \\
\hline 20:0 & 0.33 & 0.11 \\
\hline Unknown & 2.54 & 2.79 \\
\hline Total CLA & $<0.01$ & 38.36 \\
\hline
\end{tabular}

${ }^{1}$ Cows were fed a dietary rumen-protected supplement containing $205 \mathrm{~g}$ of fatty acids/d in a crossover treatment design.

During the 7-d adaptation periods, all cows received $(242 \mathrm{~g} / \mathrm{d})$ EnerGII (an RI supplement of palm fatty acid distillate; Bioproducts Inc., Fairlawn, OH; Table 1). Cows were maintained in a dry-lot pen and individually fed using the Calan Broadbent Feeding System (American Calan, Inc., Northwood, NH) for monitoring daily individual animal feed intake and application of different dietary treatments to cows housed in the same pen. The pen contained a corrugated sheet metal shade structure oriented North/South with an oscillating fan evaporative cooling system (Advanced Dairy System, Phoenix, AZ). Cows were moved to the pen, assigned to a Calan feeding door and allowed to acclimate to this feeding system for $10 \mathrm{~d}$ before trial initiation. Cows were individually fed a TMR twice daily (0600 and 1800 h) ad libitum, and orts were collected and recorded daily just before the morning feeding. The TMR was formulated to meet or exceed the predicted requirements (NRC, 2001) of energy, protein, minerals, and vitamins, using CPM-Dairy (Table 2). Alfalfa hay was the main forage source and steam-flaked corn was the primary concentrate. The TMR was sampled weekly, composited by period, and analyzed by wet chemistry methods for $\mathrm{CP}, \mathrm{ADF}, \mathrm{NDF}, \mathrm{NE}_{\mathrm{L}}$, and minerals (Dairy One Cooperative Inc., Ithaca, NY). Dietary treatments consisted of $250 \mathrm{~g} / \mathrm{d}$ of RI-CLA ( $82 \%$ lipid of which $~ 38 \%$ was mixed isomers of CLA; Bioproducts Inc.) or $242 \mathrm{~g} / \mathrm{d}$ of EnerGII (85\% lipid) to provide an equal amount of lipid (205 g/ d). The CLA supplement contained a variety of CLA isomers (Table 1). Treatment was applied twice daily 
Table 2. Ingredients and chemical composition of diets. ${ }^{1}$

\begin{tabular}{lr}
\hline Composition & \\
\hline Ingredient, \% of DM & \\
Alfalfa hay & 58.2 \\
Amino Plus $^{2}$ & 1.3 \\
Whole cottonseed $^{3}$ EnerGII $^{3}$ & 6.9 \\
Molasses & 1.6 \\
Citrus pulp & 4.2 \\
Steam-flaked corn & 8.3 \\
Mineral and vitamin mix $^{4}$ & 15.9 \\
Chemical analysis, \% of DM & 3.5 \\
CP & \\
NDF & 20.7 \\
ADF & 34.4 \\
$\mathrm{NE}_{\mathrm{L}}, \mathrm{Mcal} / \mathrm{kg}$ of $\mathrm{DM}^{5}$ & 24.0 \\
\hline
\end{tabular}

$\mathrm{NE}_{\mathrm{L}}, \mathrm{Mcal} / \mathrm{kg}$ of $\mathrm{DM}^{5}$ $\times$ fat $\%)+(0.0547 \times \mathrm{CP} \%)+(0.0395 \times$ lactose $\%)] \times$ milk production. Solids-corrected milk was calculated according to Tyrrell and Reid (1965), and production efficiency was calculated according to Drackley et al. (2003).

The Arizona Meteorological Network recorded weather data daily and this information was used to calculate the temperature-humidity index (THI). The maximum, minimum, and mean THI was calculated: $\left\{\mathrm{THI}=\left(\right.\right.$ dry bulb temperature,$\left.{ }^{\circ} \mathrm{C}\right)+[(0.36 \times$ dew point temperature, $\left.\left.{ }^{\circ} \mathrm{C}\right)+41.2\right)$ ]; Buffington et al., 1981\} each day as well as the THI at $1600 \mathrm{~h}$. Respiration rates were determined each day at $1600 \mathrm{~h}$ by counting the number of breaths in a 15-s period and multiplying this by 4 to determine breaths per minute (bpm). Surface temperatures were recorded daily at $1600 \mathrm{~h}$ at the point of the left paralumbar fossa with a Raynger MX infrared thermometer (Raytek RAYMX4PU, Santa Cruz, CA).

\section{Fatty Acid Analysis}

Milk fat from samples collected on d 1, 3, 5, 14, and 21 were extracted according to Hara and Radin (1978) and fatty acid methyl esters were prepared by the transmethylation procedure described by Christie (1982) with modifications (Chouinard et al., 1999). Fatty acid methyl esters were quantified using a gas chromatograph (Hewlett Packard GC system 6890; Wilmington, $\mathrm{DE})$ equipped with a flame ionization detector and a CP-7420 fused silica capillary column $(100 \mathrm{~m} \times 0.25$ $\mathrm{mm}$ i.d. with $0.2 \mu \mathrm{m}$ film thickness; Varian, Walnut Creek, CA). Initial oven temperature $\left(50^{\circ} \mathrm{C}\right)$ was held for $1 \mathrm{~min}$ then increased at $5^{\circ} \mathrm{C} / \mathrm{min}$ to $160^{\circ} \mathrm{C}$, held for $42 \mathrm{~min}$, and then increased at $5^{\circ} \mathrm{C} / \mathrm{min}$ to $190^{\circ} \mathrm{C}$, and held for $22 \mathrm{~min}$. Inlet and detector temperatures were maintained at $250^{\circ} \mathrm{C}$ and the split ratio was $100: 1$. Hydrogen carrier gas flow rate through the column was 1 $\mathrm{mL} / \mathrm{min}$. Hydrogen flow to the detector was $30 \mathrm{~mL} / \mathrm{min}$, airflow was $400 \mathrm{~mL} / \mathrm{min}$, and the nitrogen make-up gas flow was $25 \mathrm{~mL} / \mathrm{min}$. Peaks in the chromatogram were identified and quantified using pure methyl ester standards (GLC60; Nuchek Prep, Elysian, MN; Matreya, Inc., Pleasant Gap, PA, anhydrous milk fat; R.T. Corporation, Laramie, WY) and the CLA profile identified as previously described (Roach et al., 2002). A butter oil reference standard (anhydrous milk fat; R.T. Corporation) was used to determine recoveries and correction factors for individual fatty acids (Baumgard et al., 2000).

\section{Statistical Analyses}

Milk yield, DMI, and EBAL were analyzed with the repeated measures PROC MIXED procedure of SAS 


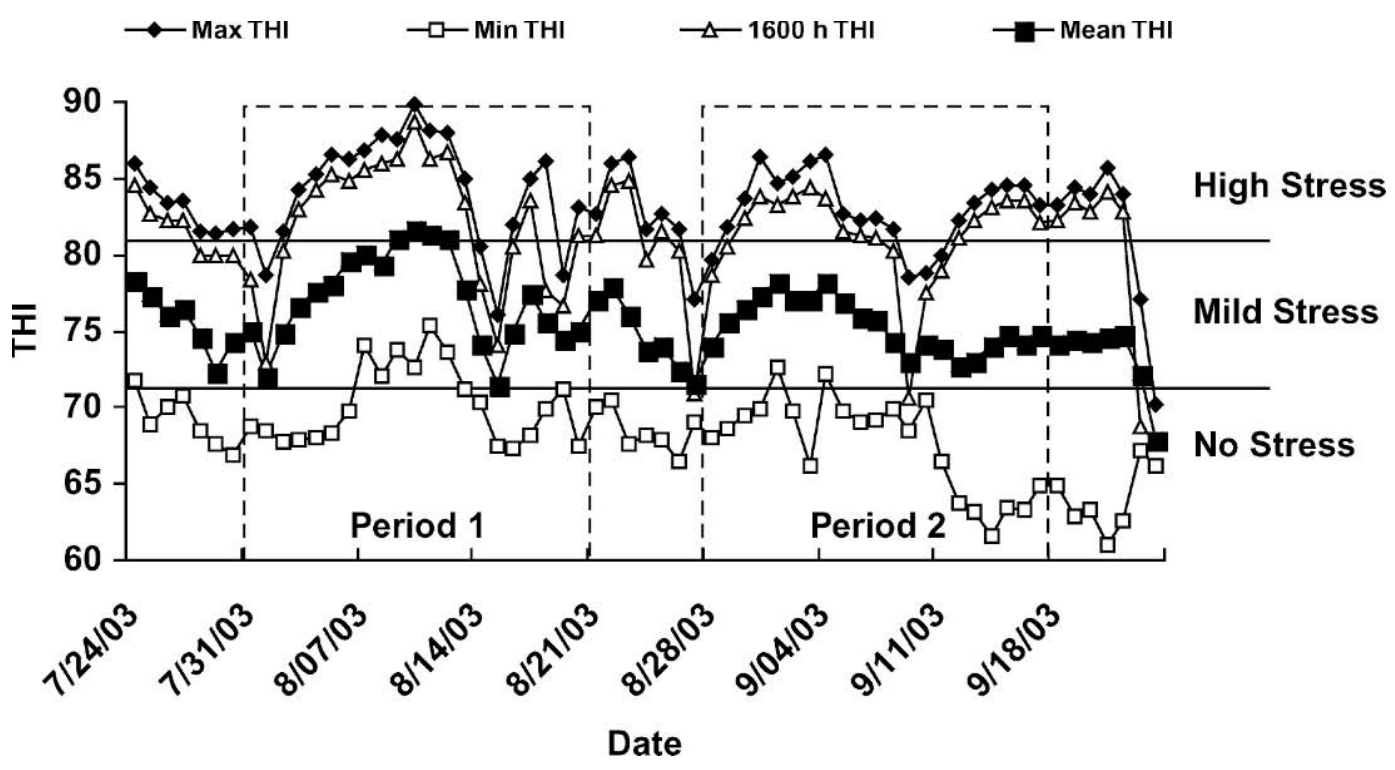

Figure 1. Temporal pattern of maximum, minimum, mean, and $1600 \mathrm{~h}$ temperature-humidity index (THI) over the trial period. Dashed boxes indicate treatment periods.

(SAS Institute, 2001) with week of treatment as the repeated effect. The model contained period, breed, treatment, week of treatment, and all possible interactions. Milk components and fatty acid profiles were also analyzed with the repeated measures PROC MIXED procedure of SAS (SAS Institute, 2001) with day of treatment as the repeated effect. The model contained period, breed, treatment, day, and all possible interactions. Both models used the autoregressive of order 1 covariance structure.

\section{RESULTS}

The maximum (83.6), mean (76.2), and THI at $1600 \mathrm{~h}$ (81.7; the time of respiration rate and skin temperature measurements) did not differ for the 2 treatment periods (Figure 1). Minimum THI was decreased $(P<0.02)$ in the second treatment period compared with the first treatment period (70.2 vs. 67.6). Respiration rate (78 $\mathrm{bpm})$ and skin temperature $\left(35.4^{\circ} \mathrm{C}\right)$ were not affected by treatment (Table 3). Respiration rate was increased $(P<0.01)$ in Brown Swiss compared with Holsteins (81 vs. $75 \mathrm{bpm}$ ), but there was no effect of breed on skin temperature.

There was no treatment effect on DMI $(23.9 \mathrm{~kg} / \mathrm{d})$, milk yield $(40.0 \mathrm{~kg} / \mathrm{d}), \mathrm{SCC}(305,000)$, protein $(2.86 \%)$, or lactose content $(4.51 \%)$, or yield of these milk components (Table 3). Supplementation with CLA decreased $(P<0.01)$ overall milk fat content and yield by 26 and
$30 \%$, irrespective of breed (Table 3 ). Reductions in milk fat content and yield were greater on d 21 (28 and $37 \%$, respectively; Figure 2). There were no breed differences for DMI, milk fat content $(2.91 \%)$ or yield $(1168 \mathrm{~g} / \mathrm{d})$, lactose content, or SCC. Holsteins produced more milk than Brown Swiss (42.8 vs. $37.3 \mathrm{~kg} / \mathrm{d}$, respectively), as well as more milk lactose (1970 vs. $1665 \mathrm{~g} / \mathrm{d}$ ) and milk SNF (3496 vs. 3101 g/d; Table 3). Protein content was increased in Brown Swiss compared with Holsteins (3.04 vs. 2.67\%), but protein yield did not differ between breeds (Table 3). Supplementation with CLA improved energy availability as predicted by calculated EBAL $(P$ $<0.03$ ) by $3.4 \mathrm{Mcal} / \mathrm{d}$ compared with the control group (7.1 vs. $3.7 \mathrm{Mcal} / \mathrm{d}$, respectively) over the course of the 21-d trial period.

On a content basis, CLA supplementation decreased overall milk fatty acids from de novo synthesis $(P<0.02$; 180.4 vs. $198.9 \mathrm{mg} / \mathrm{g}$; Table 4) and increased preformed fatty acids $(P<0.01 ; 470.5$ vs. $439.7 \mathrm{mg} / \mathrm{g})$. Total milk fat CLA content was increased $73 \%$ in the CLA supplemented cows (9.3 vs. $4.9 \mathrm{mg} / \mathrm{g})$. The concentration of the specific CLA isomers, trans-10, cis-12, and cis-11, trans-13 were also increased by CLA supplementation $(P<0.01)$, and there was a trend $(P<0.07)$ for an increase in cis-9, trans-11 CLA content. These effects of RI-CLA on fatty acid composition were independent of breed (Table 4). Milk fat from Brown Swiss had increased cis-9, trans-11 CLA $(P<0.01 ; 5.4$ vs. $4.2 \mathrm{mg} / \mathrm{g})$ and total CLA $(P<0.01 ; 8.0$ vs. $6.2 \mathrm{mg} / \mathrm{g})$ compared with Holsteins. 
Table 3. The effect of conjugated linoleic acids- (CLA-) induced milk fat depression on production and heat stress variables in lactating Brown Swiss (BS) and Holstein (H) cattle during heat stress. ${ }^{1}$

\begin{tabular}{|c|c|c|c|c|c|c|c|c|}
\hline & \multicolumn{2}{|c|}{ Treatment (Trt) } & \multicolumn{2}{|c|}{ Breed (Brd) } & SEM & \multicolumn{3}{|c|}{$P$ value } \\
\hline \multicolumn{9}{|l|}{ Production } \\
\hline $\mathrm{SCM}^{2}(\mathrm{~kg} / \mathrm{d})$ & 35.9 & 31.2 & 35.3 & 31.9 & 0.8 & $<0.01$ & $<0.01$ & 0.14 \\
\hline DMI (kg/d) & 24.4 & 23.7 & 23.7 & 24.3 & 0.7 & 0.49 & 0.53 & 0.84 \\
\hline Production efficiency ${ }^{3}$ (kg/Mcal) & 0.97 & 0.84 & 0.95 & 0.87 & 0.02 & $<0.01$ & $<0.01$ & 0.25 \\
\hline $\operatorname{EBAL}^{4}(\mathrm{Mcal} / \mathrm{d})$ & 3.7 & 7.1 & 4.8 & 6.0 & 1.0 & 0.03 & 0.39 & 0.78 \\
\hline \multicolumn{9}{|l|}{ Components } \\
\hline$\%$ & 3.35 & 2.46 & 2.84 & 2.98 & 0.08 & $<0.01$ & 0.25 & 0.44 \\
\hline $\mathrm{g} / \mathrm{d}$ & 1376 & 961 & 1209 & 1128 & 39 & $<0.01$ & 0.15 & 0.21 \\
\hline \multicolumn{9}{|l|}{ Milk protein } \\
\hline$\%$ & 2.85 & 2.87 & 2.67 & 3.04 & 0.06 & 0.85 & $<0.01$ & 0.92 \\
\hline $\mathrm{g} / \mathrm{d}$ & 1151 & 1131 & 1158 & 1124 & 33 & 0.69 & 0.48 & 0.18 \\
\hline \multicolumn{9}{|l|}{ Milk lactose } \\
\hline$\%$ & 4.53 & 4.50 & 4.54 & 4.49 & 0.04 & 0.65 & 0.45 & 0.70 \\
\hline SCC $(\times 1000)$ & 317 & 318 & 254 & 381 & 88 & 0.99 & 0.32 & 0.48 \\
\hline \multicolumn{9}{|l|}{ Heat stress measures } \\
\hline Skin temperature $\left({ }^{\circ} \mathrm{C}\right)$ & 35.4 & 35.3 & 35.3 & 35.4 & 0.3 & 0.64 & 0.80 & 0.87 \\
\hline Respiration rate (breaths/min) & 78 & 78 & 75 & 81 & 2 & 0.87 & $<0.01$ & 0.38 \\
\hline
\end{tabular}

${ }^{1}$ Data in this table represent means from the entire (21-d) trial period.

${ }^{2}$ Solids-corrected milk (Tyrrell and Reid, 1965).

${ }^{3}$ Production efficiency $=\mathrm{SCM} / \mathrm{NE}_{\mathrm{L}}$ intake $(\mathrm{kg} / \mathrm{Mcal})$.

${ }^{4} \mathrm{EBAL}=$ Net energy balance calculated according to NRC (2001), representing an average of the 21-d treatment period.

\section{DISCUSSION}

Physiological responses to heat stress in dairy cattle such as decreased DMI, increased maintenance requirements, and decreased milk production start to occur at a THI of 72 (Armstrong, 1994). Further research by Holter and coworkers (1996) suggests that a maximum daily THI of 72 will decrease DMI in dairy cattle, and a minimum THI of 56 is more closely correlated with the initiation of decreases in DMI. In the current study, the maximum THI averaged 83.6 during treatment periods, whereas minimum THI averaged 68.9 (Figure 1), which suggests that the THI (while the cows were not under the shade structure and oscillating fans) was well above the minimum needed to induce heat stress. Furthermore, respirations averaged 78 bpm, a measure typical of heat-stressed lactating dairy cattle (Kibler, 1964), and surface skin temperature averaged $35.3^{\circ} \mathrm{C}$, which is also characteristic of heat-stressed dairy cattle (Collier et al., 2003).

In agreement with other trials feeding RI-CLA to mid- and late-lactating cows (Medeiros et al., 2000; Giesy et al., 2002; Perfield et al., 2002), milk fat content and yield were decreased (26 and $30 \%$, respectively). We hypothesized that reducing milk fat during periods of heat stress, a time when nutrient availability may be limiting (due to decreased DMI), would allow for spared energy to be partitioned for increased production of milk or milk components (Bauman et al., 2001; Baumgard et al., 2002b; Collier et al., 2005). An increase in milk production and protein content has been observed on pasture-fed, CLA-supplemented dairy cows, which are frequently limited by nutrient (especially energy) availability (Medeiros et al., 2000; Mackle et al., 2003; Kay et al., 2004b). Supplementation with CLA did not affect protein or total milk synthesis under the heat stress conditions during this trial (Table 3), even though approximately $3.5 \mathrm{Mcal}$ of additional energy was available due to the CLA-induced MFD. This trial was not designed to determine the effects of CLA on reproduction, but it is conceivable that improving EBAL could alleviate some of the poor reproductive performance associated with heat stress.

Holstein cows produced more milk (4 kg/d; Table 3) and SCM $(1.7 \mathrm{~kg} / \mathrm{d}$; Table 3$)$ than Brown Swiss cows. This increase in milk yield was independent of DMI, resulting in Holsteins producing milk more efficiently $\left[\mathrm{SCM} / \mathrm{NE}_{\mathrm{L}}\right.$ intake $\left.(\mathrm{kg} / \mathrm{Mcal})\right]$. The decreased efficiency of Brown Swiss can, partially, be attributed to the fact 

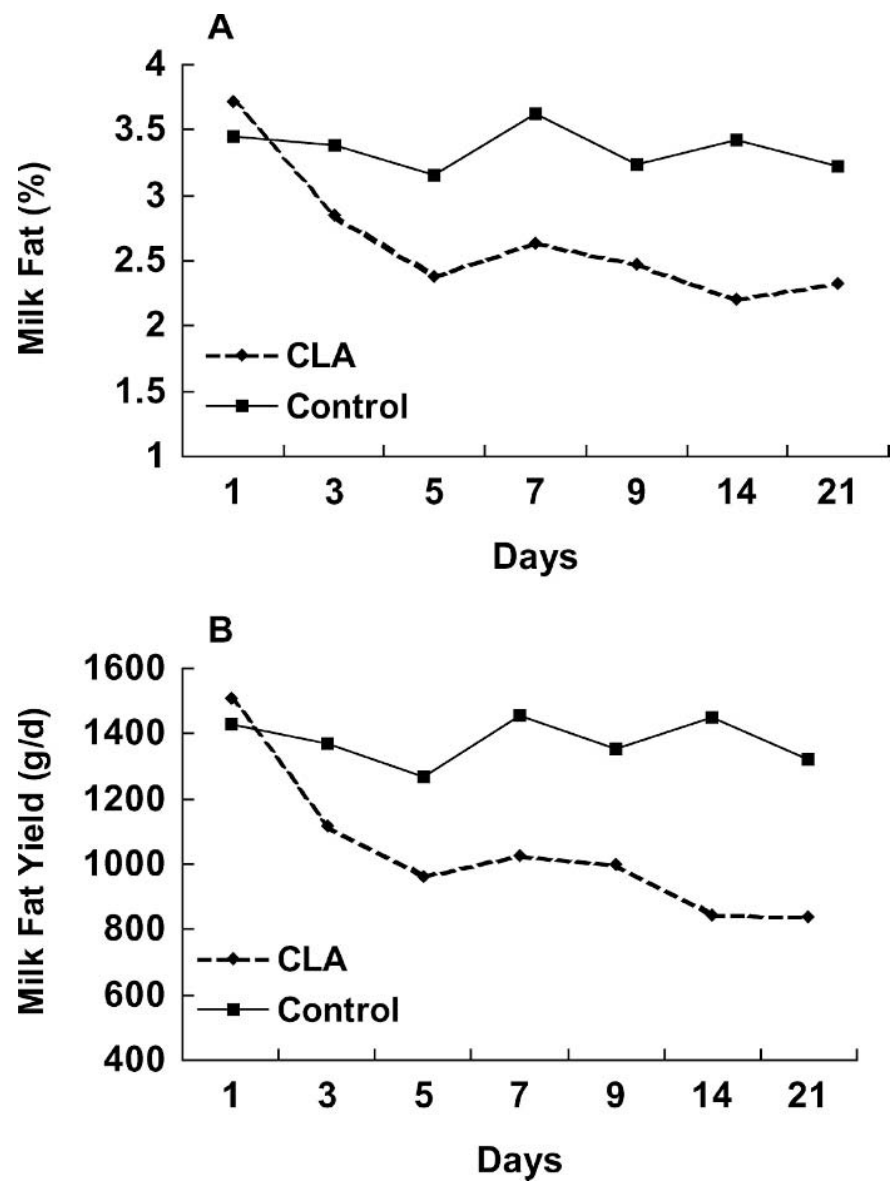

Figure 2. Temporal pattern of milk fat content (A) and milk fat yield (B) from cows fed a control diet with $242 \mathrm{~g} / \mathrm{d}$ of EnerGII or control diet supplemented with $250 \mathrm{~g} / \mathrm{d}$ of conjugated linoleic acids (CLA) during heat stress. Values are means, $\mathrm{n}=13$ for both treatment groups; SEM averaged 0.16 and ranged from 0.159 to $0.164 \%$, and averaged 72 and ranged from 71 to $78 \mathrm{~g} / \mathrm{d}$ for milk fat content and yield, respectively.

that they were, on average, $45 \mathrm{~kg}$ heavier $(P<0.04$; data not shown) than the Holsteins, resulting in increased energetic cost for maintenance of approximately 1.2 $\mathrm{Mcal} / \mathrm{d}$. This increased maintenance cost accounts for approximately $50 \%$ of the increased energy output in milk by Holsteins and helps explain why Brown Swiss had a similar EBAL compared with Holsteins even though they produced less milk while consuming a similar amount of feed (Table 3).

Use of RI-CLA increased the milk fat content of total CLA by $90 \%$, and tended to increase cis- 9 , trans-11 CLA $(P<0.07$; Table 4$)$. The changes in total and specific CLA content were independent of breed, although Brown Swiss had 29\% greater cis-9, trans-11 CLA content then Holsteins, independent of treatment. This is in contrast to previous data from the same herd that indicated Holsteins have a slightly higher cis-9, trans11 CLA content than the Brown Swiss (Kelsey et al., 2003). Reasons for the discrepancies in these 2 data sets are not clear, but most likely are due to methods of collecting data. The present study used repeated measurements of milk fat composition $(n=8)$ on each cow, where as the previous trial (Kelsey et al., 2003) used data from a single sample taken on a single day. cis-9, trans-11 CLA is predominantly synthesized through endogenous conversion of trans-11 18:1 via $\Delta^{9}$ desaturase (Corl et al., 2001; Kay et al., 2004a). In the present study there was no breed effect on the $\Delta^{9}$ desaturase system (based on the overall $\Delta^{9}$-desaturase index; Table 4). However, Brown Swiss had a higher milk fat trans-11 18:1 and lower 18:0 content, indicating the increased cis-9, trans-11 CLA levels in Brown Swiss milk fat is probably due to biohydrogenation differences resulting in an increased supply of trans-11 18:1 (the cis-9, trans-11 CLA precursor) to the mammary gland as experimentally increasing the supply of trans-11 18:1 increases the amount of cis-9, trans-11 CLA (Corl et al., 2001).

The effects of RI-CLA on milk fat synthesis, yield, and fatty acid profile were similar to results reported by others (Giesy et al., 2002; Perfield et al., 2002; Moore et al., 2004) and followed expected patterns indicating no breed effect on response to CLA-induced MFD. The decrease in milk fat did not allow for a subsequent increase in milk yield or yield of other milk components as we hypothesized. Although cows in this study were experiencing significant heat stress, the magnitude of heat stress may not have been extensive enough to induce severe negative energy balance (i.e., -10 to -15 $\mathrm{Mcal} / \mathrm{d}$ ). Controls in this experiment had an estimated negative energy balance of $3.7 \mathrm{Mcal} / \mathrm{d}$ (Table 3) and therefore milk and milk component synthesis may not have been limited by energy availability, or limited enough to detect or measure improvements in production.

Estimating EBAL during heat stress introduces 2 problems independent of those inherent to normal EBAL estimations (Vicini et al., 2002). First, considerable evidence suggests that increased maintenance costs are associated with heat stress (7 to 25\%; NRC, 1981); however, due to complexities involved in predicting upper critical temperatures, no universal equation is available to adjust for this increase in maintenance (Fox and Tylutki, 1998) when calculating EBAL in heat-stressed animals. Not incorporating a heatstress correction factor results in overestimating EBAL and inaccurate prediction of energy status. In this paper, we used data provided by the NRC (1981), which suggests an increased maintenance requirement of $20 \%$ for cows experiencing $35^{\circ} \mathrm{C}$ or greater for more than 6 
Table 4. Fatty acid composition of cows comparing treatment [control vs. conjugated linoleic acids (CLA)] and breed [Holstein (H) vs. Brown Swiss (BS)]. ${ }^{1}$

\begin{tabular}{|c|c|c|c|c|c|c|c|}
\hline \multirow[b]{2}{*}{ Fatty acid } & \multicolumn{2}{|c|}{ Treatment (Trt) } & \multicolumn{2}{|c|}{ Breed (Brd) } & \multirow[b]{2}{*}{ SEM } & \multicolumn{2}{|c|}{$P$ value } \\
\hline & Control & CLA & $\mathrm{H}$ & $\mathrm{BS}$ & & Trt & Brd \\
\hline & \multicolumn{4}{|c|}{$\mathrm{mg} / \mathrm{g}$ of fatty acids } & & & \\
\hline $4: 0$ & 25.5 & 23.7 & 23.6 & 25.5 & 0.8 & 0.11 & 0.10 \\
\hline $6: 0$ & 21.5 & 18.9 & 19.4 & 21.0 & 0.8 & 0.03 & 0.18 \\
\hline $8: 0$ & 10.8 & 9.0 & 9.4 & 10.4 & 0.5 & 0.02 & 0.14 \\
\hline $10: 0$ & 20.5 & 16.4 & 17.7 & 19.2 & 1.0 & 0.01 & 0.30 \\
\hline $12: 0$ & 22.2 & 19.3 & 20.0 & 21.4 & 1.0 & 0.05 & 0.34 \\
\hline $14: 0$ & 84.3 & 78.9 & 81.3 & 82.0 & 2.4 & 0.12 & 0.83 \\
\hline $14: 1 c-9$ & 5.8 & 5.4 & 5.3 & 5.9 & 0.3 & 0.45 & 0.18 \\
\hline 15:0 & 8.4 & 8.8 & 8.9 & 8.3 & 0.2 & 0.12 & 0.02 \\
\hline $16: 0$ & 321.6 & 309.4 & 319.9 & 311.1 & 5.0 & 0.10 & 0.22 \\
\hline $16: 1 c-9$ & 10.9 & 10.9 & 10.5 & 11.3 & 0.5 & 0.96 & 0.30 \\
\hline $17: 0$ & 5.3 & 5.8 & 5.8 & 5.4 & 0.1 & $<0.01$ & $<0.01$ \\
\hline $18: 0$ & 109.3 & 121.7 & 119.8 & 111.2 & 2.5 & $<0.01$ & 0.02 \\
\hline $18: 1 t-6-8$ & 3.8 & 3.9 & 4.0 & 3.8 & 0.1 & 0.36 & 0.20 \\
\hline $18: 1 t-9$ & 2.9 & 3.3 & 3.1 & 3.1 & 0.1 & $<0.01$ & 0.93 \\
\hline $18: 1 t-10$ & 4.8 & 5.0 & 4.9 & 4.9 & 0.1 & 0.15 & 0.64 \\
\hline $18: 1 t-11$ & 10.7 & 10.2 & 9.2 & 11.7 & 0.4 & 0.30 & $<0.01$ \\
\hline $18: 1 t-12$ & 5.7 & 5.7 & 5.8 & 5.5 & 0.2 & 0.88 & 0.19 \\
\hline $18: 1 c-9$ & 241.0 & 249.8 & 241.9 & 248.9 & 8.0 & 0.44 & 0.54 \\
\hline $18: 2 c-9, c-12$ & 36.1 & 37.9 & 38.0 & 36.0 & 1.7 & 0.44 & 0.40 \\
\hline $18: 2 c-9, t-11$ CLA & 4.6 & 5.0 & 4.2 & 5.4 & 0.1 & 0.07 & $<0.01$ \\
\hline 18:2 $c-11, t-13$ CLA & $<0.1$ & 0.8 & 0.3 & 0.4 & 0.1 & $<0.01$ & 0.14 \\
\hline 18:2 $t-10, c-12$ CLA & $<0.1$ & 0.6 & 0.3 & 0.3 & $<0.1$ & $<0.01$ & 0.20 \\
\hline Other CLA & 0.3 & 2.9 & 1.5 & 1.8 & 0.2 & $<0.01$ & 0.34 \\
\hline $18: 3 c-9, c-12, c-15$ & 12.5 & 15.5 & 14.5 & 13.5 & 4.0 & 0.59 & 0.87 \\
\hline 20:0 & 2.7 & 2.3 & 2.6 & 2.5 & 0.7 & 0.66 & 0.96 \\
\hline Unknown & 28.9 & 28.8 & 28.5 & 29.2 & 0.5 & 0.91 & 0.29 \\
\hline Total CLA & 4.9 & 9.3 & 6.2 & 8.0 & 0.4 & $<0.01$ & $<0.01$ \\
\hline Total 18:1 trans & 27.9 & 28.1 & 27.1 & 28.9 & 0.5 & 0.81 & 0.02 \\
\hline \multicolumn{8}{|l|}{$\Delta^{9}$ Ratios } \\
\hline $14: 1 / 14: 0$ & 0.07 & 0.07 & 0.06 & 0.07 & $<0.01$ & 0.93 & 0.19 \\
\hline $16: 1 / 16: 0$ & 0.03 & 0.04 & 0.03 & 0.04 & $<0.01$ & 0.63 & 0.18 \\
\hline 18:1/18:0 & 2.23 & 2.10 & 2.04 & 2.28 & 0.10 & 0.37 & 0.06 \\
\hline$c 9, t 11$ CLA/18:1 $t 11$ & 0.43 & 0.50 & 0.46 & 0.47 & 0.01 & $<0.01$ & 0.51 \\
\hline$\Delta^{9}$ Index $^{2}$ & 0.33 & 0.34 & 0.33 & 0.35 & 0.01 & 0.50 & 0.28 \\
\hline \multicolumn{8}{|l|}{ Fatty acid origin } \\
\hline De novo & 198.9 & 180.4 & 185.4 & 193.9 & 5.2 & 0.02 & 0.25 \\
\hline $16: 0$ and $16: 1$ & 332.5 & 320.3 & 330.4 & 322.4 & 5.0 & 0.10 & 0.26 \\
\hline Preformed & 439.7 & 470.5 & 455.7 & 454.5 & 8.0 & 0.01 & 0.92 \\
\hline
\end{tabular}

${ }^{1}$ Data in this table represent means from $\mathrm{d} 3,5,14$, and 21.

${ }^{2} \Delta^{9}$-Desaturase index calculated by: $\left[\left(\mathrm{C}_{14: 1}+\mathrm{C}_{16: 1}+\mathrm{C}_{18: 1}\right) /\left(\mathrm{C}_{14: 1}+\mathrm{C}_{16: 1}+\mathrm{C}_{18: 1}+\mathrm{C}_{14: 0}+\mathrm{C}_{16: 0}+\mathrm{C}_{18: 0}\right)\right]$.

$\mathrm{h} / \mathrm{d}$. Secondly, a proportionate decrease in milk yield causes calculated EBAL to remain slightly positive and thus appears adequate because of adjusted level of production. However, despite the calculated positive EBAL, irrespective of treatment, cows lost approximately $18 \mathrm{~kg}$ of BW during this trial (data not shown). In agreement, cows in established lactation from semiarid environments (e.g., Arizona, Middle East) will typically lose approximately $20 \mathrm{~kg}$ of body weight during the course of a summer (Dennis Armstrong, personal communication, 2004). The loss of body weight indicates cows in this trial were in negative energy balance, and illustrates the difficulty in accurately estimating EBAL during heat stress.
We believe it is likely that these cows were limited by energy availability to produce milk to their genetic potential. Furthermore, cows were already heat stressed at trial initiation and it is possible the deleterious effects of heat stress were too severe for CLA to overcome. It is of interest to determine if CLA-induced MFD could prevent (rather than remedy) the negative effects of heat stress, if provided to thermal-neutral animals before initiation of heat stress.

\section{CONCLUSION}

Cows in this trial were heat stressed as indicated by THI, respiration rate, and skin temperature. Feeding 
RI-CLA during heat stress to induce MFD alleviated estimated EBAL, but had no effect on milk yield or yield of other components. Rumen-inert CLA inhibited milk fat synthesis similarly in Brown Swiss and Holstein cows, whereas Brown Swiss had higher cis-9, trans-11 and total CLA content than Holstein cows.

\section{ACKNOWLEDGMENTS}

The authors express their appreciation to Dan Luchini and Bioproducts Inc. (Fairlawn, OH) for the donation of calcium salts of CLA and EnerGII. The technical advice of Dairy Nutrition Service (Chandler, AZ) and the assistance of Henry Hafliger, III, Octavio Mendivil, Sara Sanders, Mike Dwyer, and Steve and Nancy Faber is also greatly appreciated.

\section{REFERENCES}

AOAC. 2000. Official Methods of Analysis. 17th ed. Association of Official Analytical Chemists International, Gaithersburg, MD.

Armstrong, D. V. 1994. Heat stress interaction with shade and cooling. J. Dairy Sci. 77:2044-2050.

Bauman, D. E., B. A. Corl, L. H. Baumgard, and J. M. Griinari. 2001. Conjugated linoleic acid (CLA) and the dairy cow. Pages 221-250 in Recent Advances in Animal Nutrition. P. C. Garnsworthy and J. Wiseman, ed. Nottingham University Press, Nottingham, UK.

Baumgard, L. H., B. A. Corl, D. A. Dwyer, A. Sæbø, and D. E. Bauman. 2000. Identification of the conjugated linoleic acid isomer that inhibits milk fat synthesis. Am. J. Physiol. 278:R179-R184.

Baumgard, L. H., E. Matitashvili, B. A. Corl, D. A. Dwyer, and D. E. Bauman. 2002a. trans-10,cis-12 conjugated linoleic acid decreases lipogenic rates and expression of genes involved in milk lipid synthesis in dairy cows. J. Dairy Sci. 85:2155-2163.

Baumgard, L. H., C. E. Moore, and D. E. Bauman. 2002b. Potential application of conjugated linoleic acids in nutrient partitioning. Pages 127-141 in Proc. Southwest Nutr. Conf. Online. Available http://animal.cals.arizona.edu/swnmc/2002/proceedings.php. Accessed Dec. 1, 2002.

Belury, M. A. 2002. Dietary conjugated linoleic acid in health: Physiological effects and mechanisms of action. Annu. Rev. Nutr. 22:505-531.

Buffington, D. E., A. Collazo-Arocho, G. H. Canton, D. Pitt, W. W. Thatcher, and R. J. Collier. 1981. Black globe-humidity index (BGHI) as comfort equation for dairy cows. Trans. ASAE 24:711-714.

Chan, S. C., J. T. Huber, K. H. Chen, J. M. Simas, and Z. Wu. 1997. Effects of ruminally inert fat and evaporative cooling on dairy cows in hot environmental temperatures. J. Dairy Sci. 80:1172-1178.

Chouinard, P. Y., L. Corneau, D. M. Barbano, L. E. Metzger, and D. E. Bauman. 1999. Conjugated linoleic acids alter milk fatty acid composition and inhibit milk fat secretion in dairy cows. J. Nutr. 129:1579-1584.

Christie, W. W. 1982. A simple procedure for rapid transmethylation of glycerolipids and cholesteryl esters. J. Lipid Res. 23:1072-1075.

Collier, R. J., E. L. Annen, D. E. Armstrong, and A. L. Wolfgram. 2003. Evaluation of two evaporative cooling systems for dairy cattle under semi-arid conditions. J. Dairy Sci. 86(Suppl. 1):18. (Abstr.)

Collier, R. J., and D. K. Beede. 1985. Thermal stress as a factor associated with nutrient requirements and interrelationships. Pages 59-71 in Nutrition of Grazing Ruminants. L. McDowell, ed. Academic Press, New York, NY.
Collier, R. J., L. H. Baumgard, A. L. Lock, and D. E. Bauman. 2005. Physiological Limitations. Nutrient partitioning. Chapter 16 in Yields of Farmed Species: Constraints and Opportunities in the 21st Century. J. Wiseman and R. Bradley, ed. Nottingham University Press, Nottingham, UK.

Corl, B. A., L. H. Baumgard, D. A. Dwyer, J. M. Griinari, B. S. Phillips, and D. E. Bauman. 2001. The role of $\Delta^{9}$-desaturase in the production of cis-9, trans-11 CLA. J. Nutr. Biochem. 12:622-630.

Drackley, J. K., T. M. Cicela, and D. W. LaCount. 2003. Responses of primiparous and multiparous Holstein cows to additional energy from fat or concentrate during summer. J. Dairy Sci. 86:13061314.

Fox, D. G., and T. P. Tylutki. 1998. Accounting for the effects of environment on the nutrient requirements of dairy cattle. J. Dairy Sci. 81:3085-3089.

Giesy, J. G., M. A. McGuire, B. Shafii, and T. W. Hanson. 2002. Effect of dose of calcium salts of conjugated linoleic acid (CLA) on percentage and fatty acid content of milk fat in midlactation Holstein cows. J. Dairy Sci. 85:2023-2029.

Hara, A., and N. S. Radin. 1978. Lipid extraction of tissues with a low-toxicity solvent. Anal. Biochem. 90:420-426.

Holter, J. B., J. W. West, M. L. McGilliard, and A. N. Pell. 1996. Predicting ad libitum dry matter intake and yields of Jersey cows. J. Dairy Sci. 79:912-921.

Kay, J. K., T. R. Mackle, M. J. Auldist, N. A. Thomson, and D. E. Bauman. 2004a. Endogenous synthesis of cis-9, trans-11 CLA in dairy cows fed fresh pasture. J. Dairy Sci. 87:369-378.

Kay, J. K., J. R. Roche, and L. H. Baumgard. 2004b. Effects of dietary CLA on production parameters in pasture-fed transition dairy cows. J. Dairy Sci. 87(Suppl. 1):73. (Abstr.)

Kelsey, J. A., B. A. Corl, R. J. Collier, and D. E. Bauman. 2003. The effect of breed, parity, and stage of lactation on conjugated linoleic acid (CLA) in milk fat from dairy cows. J. Dairy Sci. 86:2588-2597.

Kibler, H. H. 1964. Environmental physiology and shelter engineering with special references to domestic animals. LXVII. Thermal effects of various temperature-humidity combinations on Holstein cattle as measured by eight physiological responses. Missouri Agric. Exp. Sta. Res. Bull. No. 862. Columbia, MO.

Knapp, D. M., and R. R. Grummer. 1991. Response of lactating dairy cows to fat supplementation during heat stress. J. Dairy Sci. 74:2573-2579.

Loor, J. J., and J. H. Herbein. 1998. Exogenous conjugated linoleic acid isomers reduce bovine milk fat concentration and yield by inhibiting de novo fatty acids synthesis. J. Nutr. 128:2411-2419.

Mackle, T. R., J. K. Kay, M. J. Auldist, A. K. H. McGibbon, B. A. Philpott, L. H. Baumgard, and D. E. Bauman. 2003. Effects of abomasal infusion of conjugated linoleic acid on milk fat concentration and yield form pasture-fed dairy cows. J. Dairy Sci. 86:644-652.

Medeiros, S. R., D. E. Oliveira, L. J. M. Aroeira, M. A. McGuire, D. E. Bauman, and D. P. D. Lanna. 2000. The effect of long-term supplementation of conjugated linoleic acid (CLA) to dairy cows grazing tropical pasture. J. Dairy Sci. 83(Suppl. 1):169. (Abstr.)

Moore, C. E., H. C. Hafliger, III, O. B. Mendivil, S. R. Sanders, D. E. Bauman, and L. H. Baumgard. 2004. Increasing amounts of conjugated linoleic acid (CLA) progressively reduces milk fat synthesis immediately postpartum. J. Dairy Sci. 87:1886-1895.

National Research Council. 1981. Effect of environment on nutrient requirements of domestic animals. Natl. Acad. Press, Washington, DC.

National Research Council. 2001. Nutrient Requirements of Dairy Cattle, 7th rev. ed. Natl. Acad. Press, Washington, DC.

Perfield, J. W., II, G. Bernal-Santos, T. R. Overton, and D. E. Bauman. 2002. Effects of dietary supplementation of rumen-inert conjugated linoleic acid in dairy cows during established lactation. J. Dairy Sci. 85:2609-2617.

Roach, J. A. G., M. M. Mossoba, M. P. Yurawecz, and J. K. G. Kramer. 2002. Chromatographic separation and identification of conjugated linoleic acid isomers. Anal. Chim. Acta 465:207-226. 
SAS Institute. 2001. SAS/STAT Users Guide (release 8.0) SAS Institute, Inc., Cary, NC.

Terpstra, A. H. M., A. C. Beynen, H. Everts, S. Kocsis, M. B. Katan, and P. L. Zock. 2002. The decrease in body fat in mice fed conjugated linoleic acid is due to increases in energy expenditure and energy loss in the excreta. J. Nutr. 132:940-945.

Thiel-Cooper, R. L., F. C. Parish, Jr., J. C. Sparks, B. R. Weigand, and R. C. Ewan. 2001. Conjugated linoleic acid changes swine performance carcass composition. J. Anim. Sci. 79:1821-1828.
Tyrrell, H. F., and J. T. Reid. 1965. Prediction of the energy value of cow's milk. J. Dairy Sci. 48:1215-1223.

Vicini, J. L., B. A. Crooker, and M. A. McGuire. 2002. Energy balance in early lactation dairy cows. Pages $1-8$ in Proc. Cal. Anim. Nutr. Conf.

West, J. W. 2003. Effects of heat-stress on production in dairy cattle. J. Dairy Sci. 86:2131-2144.

Whigham, L. D., M. E. Cook, and R. L. Atkinson. 2000. Conjugated linoleic acid: Implications for human health. Pharm. Res. 42:503-510. 